\title{
ANALYSIS AND DESIGN OF ZERO SEWAGE DISCHARGE SYSTEM FOR MODEL TOWNSHIP
}

\author{
Ninad B. Bhalerao ${ }^{1}$, A. R. Kambekar ${ }^{2}$ \\ ${ }^{1}$ PG. Student, Const. Management, ${ }^{2}$ Assistant Professor, CED, SPCE Andheri (W), Mumbai 400058, Maharashtra \\ boivali@yahoo.com
}

\begin{abstract}
The ability of aquatic macrophytes to accumulate large quantities of nutrients from their environment is well documented. Reed Bed Combination Techniques for the treatment of the different types of wastewater have been used by several Researchers / Scientists all over the world. This concept has the potential to achieve a zero discharge wastewater treatment system. Man has always reached for technology for development. He insists it will bring higher levels of progress. But doesn't have the patience to study the slow-growing plants nor does he understands the natural cycles. Schoenoplectus lacustris (L.), Palla (old designation Scirpus lacustris) species is capable of "removing large quantities of organic and inorganic substances from contaminated waters" proved by the research of Dr. Kaethe Seidel in 1953 [5]. She had also shown that they take up large quantities of Ballast substances including Cobalt, Copper, Nickel and Manganese from sewage water and other higher plants, including the common reed, Phragmites communis Trin, are capable of drying out and mineralizing assorted sludge combinations which are difficult to remove. The almost water-free residues contain very little if any dangerous bacteria. This technique is an Engineered Wetland System developed on the principle of Natural Wetland. This paper will discuss the potential widespread of similar systems where there is no infrastructure for Municipal waste Disposal. The Development of an appropriate Zero Discharge wastewater facility has the potential to address the source of Environmental pollution in India.
\end{abstract}

Keywords: reed beds, population equivalent, evapotranspiration, infiltration-percolation beds, Constructed Wetlands, Elephant Grasses, Cattails

\section{INTRODUCTION}

Practicing zero waste means moving toward a target in which all materials are used to their utmost potential, and the needs of human beings are integrated into a system that also protects the environment while ensuring that nothing goes to waste. It is same as achieving zero defect goals for manufacturing, or zero injury goals in the workplace especially in the Construction Sites.

Various Researchers have demonstrated the importance of naturally growing plants which help in breaking down complex substances, converting toxic into non-toxic substances, destroying pathogens, viruses, pumping oxygen, removing oil spills, controlling the $\mathrm{pH}$ values, helping to increase the groundwater and most importantly actively and naturally transforming waste water into drinking water. This all is achieved by a simple process of photosynthesis which is known to even a school going kid.

The use of Constructed Wetlands to treat effluents is not a new idea. Reeds are rough grasses growing in wet places. Reed beds can be treated as a natural and inexpensive treatment for domestic, agriculture, industrial, etc. wastes. This system can be built for a single household as well as group of households typically at a very low cost. The basic working of the system is that the Wastewater passes through the Reed Bed and cleaner water exits the system at the same level of entry. Absolutely no electricity or any heavy machineries are required as this system works under the force of gravity. The Effluent to be treated is directly beneath the soil surface and hence no chances of standing pools or mosquitoes or foul odour. The depth of the System varies from $0.5 \mathrm{~m}$ to $2.0 \mathrm{~m}$.

The Project which is considered as a Model Township is "Dream City" in the Village Boisar, District - Thane, Maharashtra. This Project is considered since there is no Municipal Sewer where the Domestic waste generated on a Daily basis can be disposed off. The Plot Area is 1,15,750 sq.mts. and the Total Population estimated is 11,340 . The Total Waste water generated is estimated at 1030 Kilo litres/day.

\section{METHODOLOGY ADOPTED}

The Methodology adopted is to formulate a Model Township to study the actual Sewage Discharge generated from daily Domestic use. The Reed Bed System is designed to achieve a Zero Discharge target where the waste water generated is treated for reuse. The Conventional Sewage Treatment Plant is 
considered for the study purpose of comparison of the Quality and the Overall Costs i.e. Capital Cost and the Operation and Maintenance Cost. The Quality of Treated and Untreated Waste water are compared to prove the effectivity of the Reed Bed System. Locally available Plant Species are being considered for the Design of the Reed Bed System.

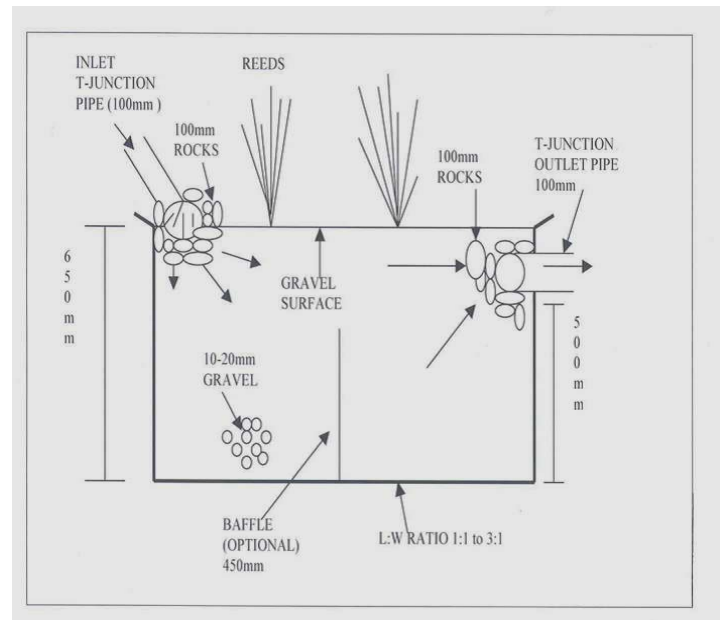

Figure 1: Basic Reed bed Design (Lateral View)

Table1. Waste Water Characteristics Before and After Treatment by Reed Bed System

\begin{tabular}{|l|l|l|l|l|}
\hline Sr. No. & Sewage Characteristics & Untreated & Treated & $\begin{array}{l}\text { Approx. } \\
\text { Efficiency } \\
\text { Removal }\end{array}$ \\
\hline 1 & $\mathrm{pH}$ & $7.0-8.0$ & $6.5-7.5$ & - \\
\hline 2 & Biological Oxygen Demand (mg/lit) & $250-300$ & $<20$ & $85 \%$ \\
\hline 3 & Chemical Oxygen Demand (mg/lit) & $350-400$ & $<250$ & $40 \%$ \\
\hline 4 & Total Suspended Solids (mg/lit) & $150-250$ & $<20$ & $83 \%$ \\
\hline 5 & Nitrogen (mg/lit) & $25-35$ & $<10$ & $60 \%$ \\
\hline 6 & Phosphorous (mg/lit) & $2.5-4.0$ & $<1.5$ & $46 \%$ \\
\hline 7 & Fecal Coliform (colonies/100ml) & $3 \times 107-4.5 \times 107$ & $<2 \mathrm{X} 106$ & $96 \%$ \\
\hline
\end{tabular}

Table2. Environment Management Cost

\begin{tabular}{|c|c|c|c|c|c|}
\hline \multirow{2}{*}{$\begin{array}{l}\text { Sr. } \\
\text { No. }\end{array}$} & \multirow{2}{*}{ Particulars } & \multirow{2}{*}{$\begin{array}{l}\text { Capital Cost } \\
\text { (In Lakhs } \\
\text { Rs.) }\end{array}$} & \multirow{2}{*}{$\begin{array}{l}\text { Operation and } \\
\text { Maintenance Cost } \\
\text { (In Lakhs Rs.) }\end{array}$} & \multicolumn{2}{|c|}{$\begin{array}{l}\text { \% Cost Savings } \\
\text { (In Lakhs Rs.) }\end{array}$} \\
\hline & & & & $\begin{array}{l}\text { Capital } \\
\text { Cost }\end{array}$ & $\begin{array}{l}\text { Maintenan } \\
\text { ce Cost }\end{array}$ \\
\hline 1 & $\begin{array}{l}\text { Sewage Treatment Plant } \\
\text { - STP }\end{array}$ & 220 & 25 & \multirow{3}{*}{$56 \%$} & \multirow{3}{*}{$80 \%$} \\
\hline 2 & $\begin{array}{l}\text { Constructed Wetlands } \\
\text { System }\end{array}$ & 95 & 5 & & \\
\hline Total & & 315 & 30 & & \\
\hline
\end{tabular}




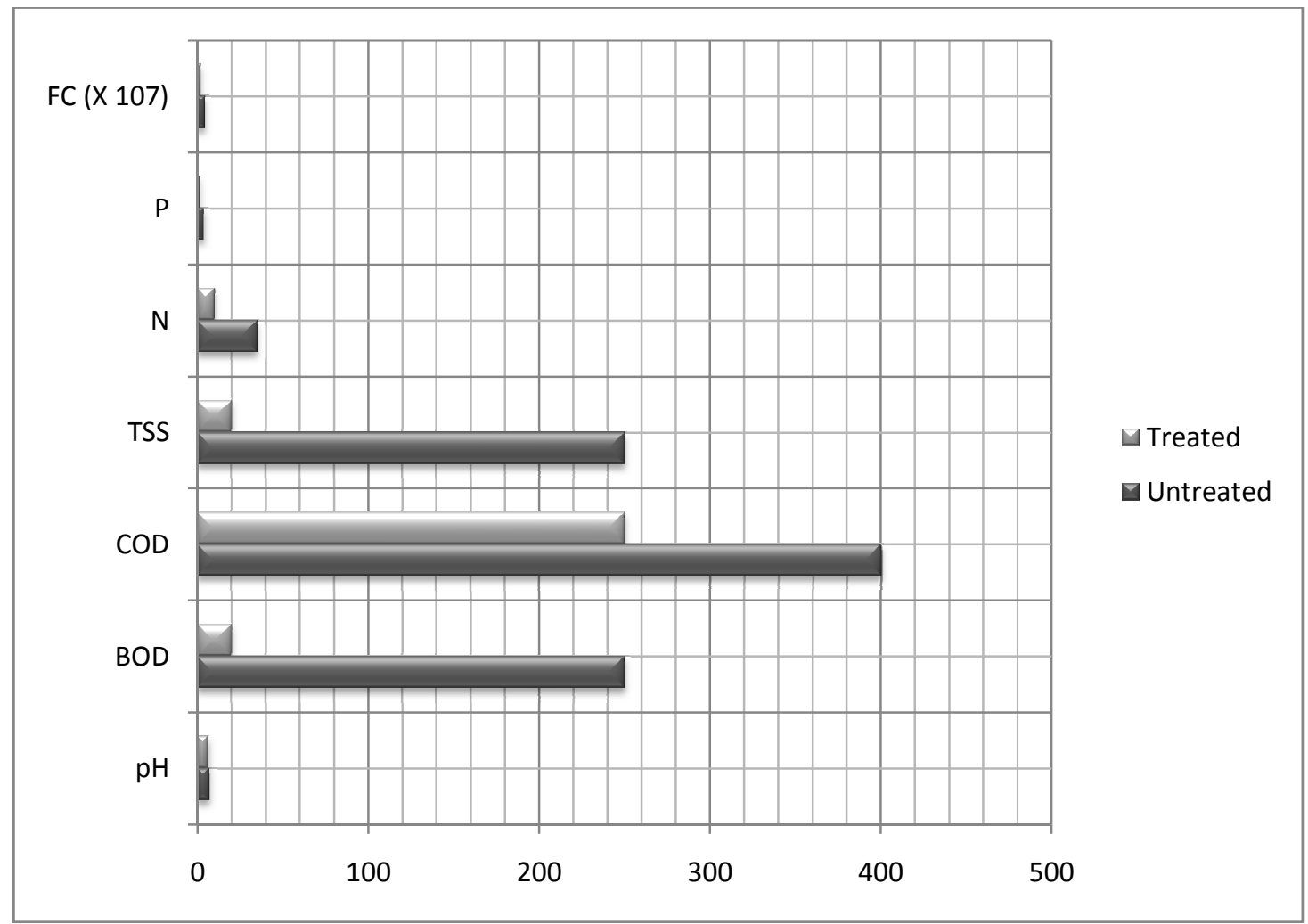

Figure2. Waste Water Characteristics before and after Treatment by Reed Bed System

\section{Capital Cost in Lakhs}

(Rs.)

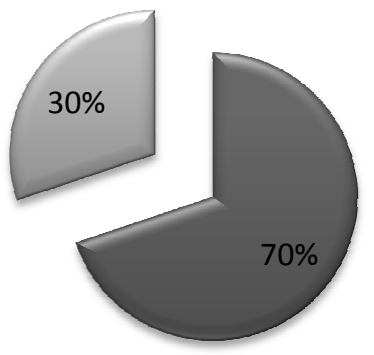

$\square$ Sewage
Treatment
Plant
Constructed
Wetlands
System

Figure3A. Environment Management Cost

\section{Operation \& Maintenance Cost in Lakhs (Rs.)}

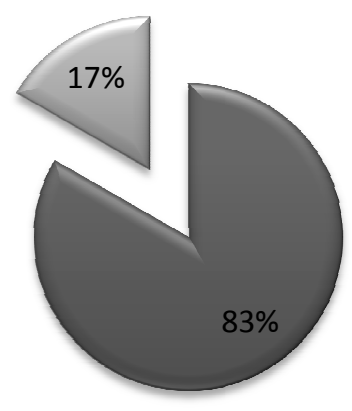

$\square$ Sewage

Treatment Plant

$\square$ Constructed Wetlands System 


\section{RESULTS AND DISCUSSION}

The Reed Bed System as a Constructed Wetland has time and again proved that "Use of Natural Resources" to treat the onsite wastewater will always be an effective and dynamic option not only in giving the desired output of the Effluent to be discharge but also a technique or procedure which can directly connect to the masses or general public. The Conventional Methods of Wastewater Treatment are sadly today prevalent with the Construction Industry due to the stigma of the Environmentalists in India to design all projects with systems only to get the Government or the Pollution Board Clearances and finish the project on deadline. Hence, it is the responsibility of the Environmentalists to bring to the common masses the new or improved technologies not only on paper but also in general practice and use. Today, plants are the only natural resource which has the potential to adapt itself to the Human onslaught on our environment. Hence, today the burning issue is to have more and more use of plants, reeds, willows, bulrushes in our day to day modern lifestyles.

\section{RECOMMENDATIONS}

The Reed Bed System as a Constructed Wetland has time and again proven that use of Natural Resources to treat the on-site wastewater will always be an effective and dynamic option not only in giving the desired output of the Effluent to be discharge but also a technique or procedure which can directly connect to the masses or general public. The conventional methods of wastewater treatment are sadly today prevalent with the Construction Industry due to the stigma of the Environmentalists in India to design all projects with systems only to get the Government or the Pollution Board Clearances and finish the project on deadline. Hence, it is the responsibility of the Environmentalists to bring to the common masses the new or improved technologies not only on paper but also in general practice and use. Today, plants are the only natural resource which has the potential to adapt itself to the Human onslaught on our environment. Hence, today the burning issue is to have more and more use of plants, reeds, willows, bulrushes in our day to day modern lifestyle.

\section{REFERENCES}

[1] Connett, P., and Sheehan, B., "Citizens Agenda for Zero Waste: A North American Perspective," GRRN, October 2001

[2] Parker, D. S., "Wastewater Technology Innovation For The Year 2000" Environmental Engineering Lecture, at the July 7, 1987, National Conference on Environmental Engineering, held at Orlando, FL.

[3] Hogain, O., McCarton, S., Reid, A., ; A review of zero discharge wastewater treatment systems using reed willow bed combinations in Ireland, Journal of Water Practice and Technology, Volume 6, No. 3, 2011

[4] Latha, N., Deepa, N., Anand, B. K., Raju, K. V., Shashidhara, H. L., "Wastewater Reuse in Megacities -
Emerging Trends in Bangalore city", Drinking Water Session of the IWMI-TATA Partners Meet to be held on February 24-26, 2005 in Anand, Gujarat

[5] Sahtouris, E., "Beautiful Bulrushes, Remarkable Reeds: The Water Reclamation Miracles Of Kaethe Seidel". Copyright 1990 by Elisabet Sahtouris.

[6] Carreras, E., "A Program Designed To Reduce The Cost And Volume Of Waste To Zero", 2 Annual Conference on Recycling of Fibrous Textile and Carpet Waste, May 19-21,1997 Atlanta, Georgia

[7] Mbuligwe, S. E., Kaseva, M. E., and Kassenga, G. R., "Applicability of Engineered Wetland Systems for Wastewater Treatment in Tanzania - A Review", School of Environmental Science and Technology, The Open Environmental Engineering Journal, 2011, 4, 1831

[8] Killion, Shannon M., "Design and Modeling of Infrastructure for Residential and Community Water Reuse" (2011). Environmental Engineering Theses and Graduate Student Research. Paper 2.

[9] Jafari, N., " Ecological and socio-economic utilization of water hyacinth (Eichhornia crassipes Mart Solms)" $J$. Appl. Sci. Environ. Manage. June 2010 Vol. 14 (2) 43 49.

[10] Ramprasad, C., " Experimental study on waste water treatment using lab scale reed bed system using Phragmitis australis " International Journal of Environmental Sciences Volume 3, No 1, 2012.

[11] Lee, J. E., Seo, S. G., Kim, B. K., Woo, S. M., Koo, B. C., Park, T. H., Lim, Y. P., and Kim, S. H., " Induction of somatic embryogenesis and plant regeneration in the reed grass (Phragmites communis Trin.) " African Journal of Biotechnology Vol. 11(8), pp. 1904-1911, 26 January, 2012.

[12] Trivedy, R. K., " Low Cost and Energy Saving Technologies for Water and Wastewater Treatment" Journal of Industrial Pollution Control 23(2) (2007) pp 403-411.

[13] McCarton, L., O'Hogain, S., McDonald, D., Reid,A.; "Lynches Lane Reed and Willow Bed Facility Final Report”, South Dublin County Council, January 2012.

[14] Manderia, S., " Performance Evaluation of Reed Grass (Phragmites karka) in Constructed Reed Bed System (CRBs) on Domestic sludge, Ujjain city, India", Research Journal of Recent Sciences Vol. 1(ISC-2011), 41-46 (2012).

[15] Kantawanichkul, S., Sattayapanich, S., and Dien, F., "Treatment Of Domestic Wastewater By A Subsurface Vertical Flow Constructed Wetland System Planted With Umbrella Sedge And Vetiver Grass", Ecological Engineering Journal.35(2):238-247.

[16] Gupta, P., Roy, S., and Mahindrakar, A. B., "Treatment of Water Using Water Hyacinth, Water Lettuce and Vetiver Grass - A Review", Resources and Environment 2012, 2(5): 202-215. 